\title{
Role of the phosphatase PP4 in the activation of JNK-1 in prostate carcinoma cell lines PC-3 and LNCaP resulting in increased AP-1 and EGR-1 activity
}

\author{
JUAN INOSTROZA ${ }^{1}$, LEONARDO SÁENZ1 ${ }^{1}$, GLORIA CALAF $^{2}$, \\ GERTRUDIS CABELLO ${ }^{2}$ and EDUARDO PARRA ${ }^{1}$
}

\author{
${ }^{1}$ Instituto de Ciencias Biomédicas, Facultad de Medicina, Universidad de Chile, Santiago, Chile. \\ ${ }^{2}$ Departamento de Biología y Salud. Facultad de Ciencias, Universidad de Tarapacá, Arica, Chile.
}

\begin{abstract}
The specific signaling connections between the mitogen-activated protein kinases (MAPK) such as c-Jun Nterminal kinase (JNK-1) and phosphatases PP4 and M3/6, affecting the family of early nuclear factors, is complex and remains poorly understood. JNK-1 regulates cellular differentiation, apoptosis and stress responsiveness by up-regulating early nuclear factors such as c-Jun, a member of the activating protein (AP1) family, and the Early Growth Factor (EGR-1). C-Jun, when phosphorylated by c-Jun N-terminal kinase (JNK-1) associates with c-Fos to form the AP-1 transcription factor that activates gene expression. We have investigated the regulation of the JNK-1 kinase by co-transfecting phosphatases PP4 and M3/6 in prostate cancer cell lines PC-3 and LNCaP, which have been previously stimulated with human EGF or cisplatin. Cotransfections of plasmids expressing the JNK-1 and the serine/threonine phosphatases PP4 resulted in a significant increase in JNK-1 activity in both PC3 and LNCaP cells. In contrast, co-transfection of JNK-1 with the dual specific phosphatase serine/threonine M3/6 showed only a marginal effect in JNK-1 activity. The phosphatase M3/6 also failed in blocking the induction of JNK-1 activity observed in presence of PP4. The higher activity of JNK-1 was associated with increased activities of the factors c-Jun/AP-1 and EGR-1. This suggests that JNK-1 activity in PC-3 and LNCaP cells requires not only active PP4 for stable maintenance but also suggests that the relative degree of phosphorylation of multiple cellular components is the determinant of JNK-1 stability.
\end{abstract}

Key terms: prostate cancer, phosphatase PP4, kinase JNK-1

\section{INTRODUCTION}

The MAPK family consists of a group of three different kinase pathways: the extracellular signal-regulated kinases (ERK1/2), a.k.a. p44/42 (Robinson et al., 1996); the Jun-N-terminal kinases (JNKs), a.k.a. SAPK (stress-activated protein kinases) (Blenis, 1993; Cobb et al., 1995); and the p38 kinase, which is usually activated by environmental stresses and correlated with programmed cell death (Ip \& Davis, 1998; Derijard et al., 1994; Foltz et al., 1998; Hibi et al., 1993). Recently, an important role of the JNK-1/2 member of the MAP kinases has been proposed in prostate cancer. JNK-1 is activated by dual phosphorylation of Thr and Tyr residues within a Thr-Pro-Tyr motif located in kinase sub domain VIII (Sánchez et al., 1994; Tournier et al., 1997). Once activated, JNK-1 can up-regulate gene expression by phosphorylating the activating motif of transcription factors such as ATF2 (Gupta et al., 1995; Bocco et al., 1996), cJun and JunD (Hibi et al., 1993; GroverBardwick, et al., 1994), and the Ets domain of transcription factors Elk-1 and Sap-1 (Minden et al., 1994; Smeal et al., 1992; Janknecht et al., 1993; Janknecht and Hunter 1997). The activation of the transcription

Corresponding author: Eduardo Parra, Ph.D. Signal Transduction and Gene Therapy Lab, Disciplinary Program of Pharmacology, ICBM. Faculty of Medicine, Universidad de Chile, Av. Independencia 1027, Santiago, Chile, Tel.: (56-2) 978-6654, Fax: (56-2) 737-2783,E-mail: eparra@med.uchile.cl 
factor AP-1 mediated by JNK-1, by means of phosphorylation of c-Jun, has been implicated in oncogenic transformation (Karin, 1995). Transcription factor phosphorylation by protein kinases has received a great deal of attention in the study of prostate cancer, in contrast, very little is known about the implications of protein phosphatases (PP) and de-phosphorylation in this type of cancer. The phosphorylation of MAP kinases (MAPK) in vivo is a reversible process, indicating that protein phosphatases provide an additional level of regulation of MAPKs functions (Mustelin et al., 2005). A group of dual-specificity kinase phosphatases, (MAPs), has been identified that inactivates MAPKs through dephosphorylation of both threonine and tyrosine residues (Guan et al., 1991). These phosphatases include ERK-specific MKP-1, -2 and -3 (Fanger, 1997; Haneda et al., 1999; Keyse, 1998) and JNK-1/2 and p38-specific M3/6 (Muda et al., 1996). There is growing evidence suggesting that protein phosphatases are implicated in prostate cancer. The phosphatase PTEN, also a dual specificity protein phosphatase, is inactivated in a significant proportion of prostate carcinoma, which suggests that its inactivation is associated with the metastatic stage of prostate cancer (Yen et al., 1997; Vliestra et al., 1998). The mitogen-activated protein kinase 1 phosphatase (MKP-1) is over-expressed in the pre-invasive stage of prostate cancer, showing decrease levels in the advanced stage of the disease, suggesting that over-expression of MKP-1 could be associated with the early phase of prostate cancer (Muda et al., 1996)

The phosphatase PP4 (also called PPX), a novel serine/threonine phosphatase, seems to play a key role in the regulation of JNK-1 expression. PP4 is structurally related to the PP2A family of enzymes (with $65 \%$ amino acid sequence identity) and contains putative okadaic acid and microcystin-LR binding domains (Cohen, 1997; Shiozaki \& Russell, 1995). PP4 has been highly conserved during evolution (Cohen, 1990; 1997). The deduced amino acid sequence of human PP4, assigned to chromosome 16p11-p12, differs from the sequence of rabbit PP4 only in two of 307 amino acids (Cohen, 1990; 1997).
This high degree of conservation suggests that PP4 is involved in critical cellular events. Since PP4 is found predominantly in centrosomes, microtubule nucleation could be one of such event (Shiozaki and Russell, 1995; Zhou et al., 2002). However, the molecular mechanisms by which PP4 functions in cellular signaling remain to be determined. Another factor that is overexpressed in prostate cancer is the Early Growth Response-1 (EGR-1), which is a member of the immediate-early gene family that includes Fos, Jun, and other early growth response genes (You et al., 1997; Mora et al., 2004; Baron et al., 2003). EGR1 gene encodes a DNA-binding protein that contains zinc finger motifs, expressed in many cell types in response to a wide variety of mitogenic and non-mitogenic stimuli, including peptide growth factors, shear stress, urea and hypotonicity (Pipaon et al., 2004; Keeton et al., 2003). Once activated, EGR-1 binds to 5'-GCGGGGGCG-3' consensus sequences within the promoter region of target genes, resulting in transcriptional activation or repression (Virolle et al., 2001).

It is know that the chemotherapeutic agent cisplatin, which damages DNA through the formation of bi-functional platinum adducts, but not transplatin, which does not damage DNA (Zamble et al., 1995), activates JNK/SAPK up to 10-fold in a dose-dependent manner. Furthermore, inhibition of this pathway in cells modified by expression of a non-phosphorylatable dominant negative mutant of c-Jun, dn-cJun, blocks DNA repair as judged by quantitative PCR and markedly decreases viability following treatment with cisplatin but not transplatin. Thus, JNK/SAPK is activated by cisplatin-induced DNA damage and is required for DNA repair and survival following cisplatin treatment (Potapova et al., 1997). These observations indicate that the JNK/SAPK pathway is activated by cisplatin-induced DNA damage and that this response is required for DNA repair and viability following cisplatin treatment (Zamble et al., 1995). Another activator of the JNK-pathway is the well-known epidermal growth factor (EGF). Autocrine and paracrine growth 
stimulation by EGF and related molecules have been implicated in the transformation of a variety of human tumors. EGF stimulates the proliferation of several kinds of human tumor cells such as gliomas (Lund-Johansen et al., 1990), mammary tumor cells (Adamson et al., 1997), and keratinocytes (Hashimoto et al., 1994). EGF, as well as transforming growth factor (TGF) and heparin binding-EGF (HB-EGF), binds to EGF-Receptor (EGFR). Several studies have also shown that EGF also plays a major role in authocrine growth of human non-small-cell lung cancer cells (NSCLC) (Hashimoto et al., 1994; Tateishi et al., 1990).

In view of this information, it seems that the activation of JNK-1, when activated by EGF or cisplatin, might rely on a delicate balance in which protein phosphatases, such as PP4, play a key role counteracting the affects of protein phosphorylation. In this study, we demonstrate that the activation of JNK-1, in prostate carcinoma cell lines PC3 and LNCaP treated with cisplatin and EGF, was dependent on the phosphatase PP4, and this resulted in the induction of DNA binding and transcription activities of nuclear factor AP-1 and EGR-1. The sum of the results presented here suggests that PP4 may play an important role in prostate carcinogenesis through the positive regulation of JNK-1 and JNK-mediated proliferation and drug resistance.

\section{MATERIALS AND METHODS}

\section{Reagents}

The protease inhibitors phenylmethylsulfonyl fluoride (PMSF), leupeptin, pepstatin, aprotinin and bestatin were purchased from Roche (USA); [9- $\left.{ }^{32} \mathrm{P}\right]$ ATP was purchased from Amersham (USA). T4 polynucleotide kinase and poly $(\mathrm{dI}-\mathrm{dC})_{2}$ were obtained from Amersham Pharmacia Biotech (Piscataway, NJ). Tris-Borate-EDTA buffer and acrylamide-bisacrylamide (29: 1) were obtained from Bio-Rad (Richmond, CA). Luciferase assay reagent, lysis buffer and the pGL-2 luciferase vector were obtained from Promega (Madison, WI). Recombinant
Human Epidermal Growth Factor (rhEGF) and Tumor Necrosis Factor alpha (TNFa) were purchased from BDBiosciences (USA). Anti-HA antibody (12CA5) was purchased from Roche Molecular Biochemicals. Monoclonal anti-Flag (M2) was purchased from Sigma. Anti-PP4 antibody was bought from Santa Cruz Biotechnology (Santa Cruz, CA, USA). MBP was purchased from Stratagene (La Jolla, CA, USA). Luciferase assay reagent, lysis buffer and the pGL-2/ pGL-3 luciferase vector were obtained from Promega (Madison, WI). GST-cJun (1-79) and GST-ATF-2 (1-96) were a gift from Dr. Roger Davis (Howard Hughes Medical Institute, MA, USA). Production and purification of GST-cJun and GST-ATF-2 proteins were performed as described previously (Ahmed et al., 2001).

\section{Plasmids}

Human JNK-1 was a gift from Dr. Dan Mercola (Sydney Kimmel Cancer Center). The dn-c-Jun was obtained from Dr. Michael Karin (University of California, San Diego, CA, USA) and the M3/6 was a gift from Dr. N. Rodriguez (University of Oxford, Oxford, UK). The PP4 cDNA was cloned from HeLa lgt11 cDNA library. The cDNA, which encompassed the complete open reading frame, was blunt end ligated into EcoRV digested pBluescript (Stratagene) to create pKS/PP4 and sequenced. The resulting plasmids were prepared by two rounds of Cesium Chloride centrifugation. The constructs for GST-Jun (1-79) and GSTATF-2 (1-96) were gifts from Dr. Roger David. Dr. Eduardo Rodríguez (Rudbeck Laboratory, Uppsala, Sweden) provided MKK6-expression plasmid. The PKC-z expression plasmid was a gift from Dr. Jose Arteaga (Karolinska Institute, Stockholm, Sweden).

\section{Cell culture and transfection}

Human carcinoma cells lines PC-3, LNCaP and DU145 were a gift from Dr. Pavel Pisa (Karolinska Institute, Stockholm, Sweden). Kiras-267B1 was a gift of Dr. Dan Mercola. PC3 and LNCaP cells were cultured in RPMI medium and DU145 cells were 
cultured in DMEM medium. Both mediums were supplemented with $10 \%$ fetal bovine serum and 100 units/ml streptomycin/ penicillin, and cells were grown at $37^{\circ} \mathrm{C}$ in a humidified atmosphere of $7 \% \mathrm{CO}_{2}$. Transient transfections were done using LipofectAMINE (Life Technologies, Inc.). Cells were plated at a density of $1 \times 10^{6}$ cells/100-mm dish and transfected the next day. Cells were transfected with plasmids encoding B-galactosidase in combination with empty vector or various amounts of plasmids encoding the phosphatases PP4 and M3/6, the kinases JNK-1, MKK6 and PKC $\mathrm{z}$, and expression plasmids for wild type and mutated c-Jun and c-Fos.

To assay for luciferase activity, transfected cells in duplicate wells were cultured for 24 hours before being stimulated with or without EGF $(50 \mathrm{nM})$ for a defined length of time. Cells were harvested, washed twice in PBS and treated with lysis buffer (Luciferase Assay Promega, Madison, WI) for 5-10 minutes on ice. Lysates were spun down for 1 minute, and the total supernatants were analyzed using luciferase Reagent (Promega) and measured in a luminometer (MicroLumat LB 96 P, Berthold) for five seconds. Background measurement was subtracted from each duplicate, and experimental values are expressed either as recorded light units, luciferase activity or as relative activity compared to extracts from un-stimulated cells (Parra et al., 1997; 1998).

\section{UV irradiation}

The UV light source was a germicidal lamp in a laminar flow chamber emitting light at a wavelength of $254 \mathrm{~nm}$. The intensity of incident UV rays at $254 \mathrm{~nm}$ was calibrated using a digital radiometer Model DM254HA from Spectroline (Westbury, NY, USA). After standardization of conditions, the distance between the plate and the lamp was maintained at $6.5 \mathrm{~cm}$, providing a fluence rate of $9 \mathrm{~J} / \mathrm{s} / \mathrm{m} 2$. All experiments used cells cultured in $60-\mathrm{mm}$ plastic tissue culture dishes containing $10 \mathrm{ml}$ of medium. The lid of the culture dish was removed for the duration of UV exposure. Fluence values were adjusted for transmittance of light to the surface of the monolayer, which was estimated at $2.5 \%$, using a Shimadzu UV-VIS spectrophotometer (Kyoto, Japan) in transmittance mode. After exposure, plates were placed in a dark incubator and maintained for 1 hour prior to nuclear extracts preparation.

\section{Preparation of nuclear extracts}

Nuclear extracts were prepared as previously described (Parra et al., 1997). Briefly, 3 - 5 x $10^{7}$ prostate cells were stimulated as above. After stimulation, they were harvested and washed once in ice-cold Phosphate Buffered Saline (PBS), washed again in buffer A (10 mM HEPES, pH 7.9, $15 \mathrm{mM} \mathrm{KCl}, 2 \mathrm{mM} \mathrm{MgCl} 2,6 \mathrm{mM}$ DTT, 0.1 $\mathrm{mM}$ EDTA and $1 \mathrm{mM}$ PMSF) and lysed in buffer A with $0.2 \%$ Nonidet P-40. The pelleted nuclei were re-suspended in buffer B (50 mM HEPES ( $\mathrm{pH} 7.6), 50 \mathrm{mM} \mathrm{KCl}$, $0.1 \mathrm{mM}$ EDTA, $1 \mathrm{mM}$ DTT, $1 \mathrm{mM}$ PMSF and $10 \%$ glycerol), in the presence of $0.3 \mathrm{M}$ (NH4) 2SO4 (pH 7.9), and rocked for 30 min at $4{ }^{\circ} \mathrm{C}$. The broken nuclei were centrifuged for $10 \mathrm{~min}$ at $100,000 \mathrm{xg}$. A 125 $\mu l$ aliquot of supernatant was transferred to a second tube and more (NH4)2SO4 was added to a final concentration of $1.5 \mathrm{M}$ followed by a second centrifugation of $50,000 \mathrm{~g}$ for $5 \mathrm{~min}$. The supernatant was removed and the pellet re-suspended in 50 $\mu l$ of buffer $\mathrm{B}$ and stored at $70^{\circ} \mathrm{C}$. Protein concentration was estimated using the BioRad stain (Richmond, CA, USA) protein assay kit with bovine albumin as standard.

\section{Western blotting}

PC-3, LNCaP, DU145, 293 and Vero and Prostate Primary Carcinoma cells were plated at a density of $2 \times 105$ per $35 \mathrm{mM}$ dish, 24 hours prior to treatment. All cultures were lysed in RIPA buffer $(50 \mathrm{mM}$ Tris-HCl pH 7.4, $150 \mathrm{mM} \mathrm{NaCl}, 1 \mathrm{mM}$ PMSF, $1 \mathrm{mM}$ EDTA, $5 \mu \mathrm{g} / \mathrm{ml}$ Aprotinin 5 $\mu \mathrm{g} / \mathrm{ml}$ Leupeptin, $1 \%$ Triton $\mathrm{x}-100,1 \%$ Sodium deoxycholate, $0.1 \%$ SDS). Lysates were heated at $100^{\circ} \mathrm{C}$ for 10 minutes. Equal volumes of extracts were separated by SDS/ PAGE on a $10 \%$ polyacrylamide gel and 
transferred to nitrocellulose. Membranes were incubated with SAP/JNK, p38 or ERK-1/2 antibody (dil. 1: 1000), PP4 antibody (dil. 1: 1000) (Santa Cruz Biotechnology). Primary incubation was followed by incubations with HRPconjugated secondary antibody (1: 2000) (NEB), and detection was with super signal chemiluminescent substrate.

\section{Electrophoretic mobility shift assay (EMSA)}

The double-stranded oligonucleotides corresponding to the consensus sequence of AP-1 and EGR-1 were (coding strand): 5'CTAGTGATGAGTCAGCCGGATC-3', and 5'-GGATCCAGCGGGGG C G A G C G G G G G C G A A C G - 3', respectively. Sp-1 consensus 5'G A T C A T A T C T G C G G G G C GGGGCAGACACAG3' as a heterologous competitor. 1 to $2 \mu \mathrm{l}$ of nuclear extract corresponding to $5-10 \mu \mathrm{g}$ of protein were added to $4 \mu \mathrm{l}$ binding buffer containing 2 to $3 \mu \mathrm{g}$ poly (dI-dC) 2 as a non-specific competitor. The reaction mixtures were incubated at $37^{\circ} \mathrm{C}$ for $30 \mathrm{~min}$ with 15,000 cpm of double-stranded 32P-labeled oligonucleotides in a final volume of $15 \mu \mathrm{l}$. The samples were electrophoresed on $5 \%$ polyacrylamide gels in $89 \mathrm{mM}$ Tris, $89 \mathrm{mM}$ boric acid, $2 \mathrm{mM}$ EDTA. The gels were fixed in $40 \%$ methanol and $10 \%$ acetic acid for $15 \mathrm{~min}$, dried and visualized by autoradiography (Parra et al., 1997).

\section{Kinase assays}

Assay of ERK Activity: Cells were incubated in the absence of serum for 16 hours and then treated with various agents. They were then washed twice with PBS and lysed in ice-cold lysis buffer $(50 \mathrm{mM}$ HEPES, pH $7.5,150 \mathrm{mM} \mathrm{NaCl}, 10 \%$ glycerol, $1 \%$ Triton X-100, $1.5 \mathrm{mM} \mathrm{MgCl2,} 1 \mathrm{mM}$ EDTA, $10 \mathrm{mM}$ sodium pyrophosphate, 100 $\mu \mathrm{M}$ sodium orthovanadate, $100 \mathrm{mM} \mathrm{NaF}$, $10 \mu \mathrm{g} / \mathrm{ml}$ aprotinin, $10 \mu \mathrm{g} / \mathrm{ml}$ leupeptin and $1 \mathrm{mM}$ phenylmethylsulfonyl fluoride) (Keyse, 1998). The extracts were centrifuged to remove cellular debris, and the protein content of the supernatants was determined using the Bio-Rad protein assay reagent. $300 \mu \mathrm{g}$ of protein from the lysate samples was used for immunoprecipitation by treatment with ERK2 rabbit polyclonal antibody at $4{ }^{\circ} \mathrm{C}$ for 2 hours. The immunoprecipitated products were washed once in lysis buffer; twice in $0.5 \mathrm{M} \mathrm{LiCl}$, $0.1 \mathrm{M}$ Tris, $\mathrm{pH}$ 8.0; and twice in kinase assay buffer (25 mM HEPES, pH 7.2-7.4, $10 \mathrm{mM} \mathrm{MgCl} 2,10 \mathrm{mM} \mathrm{MnCl} 2$ and $1 \mathrm{mM}$ dithiothreitol), and the samples were resuspended in $30 \mu \mathrm{l}$ of kinase assay buffer containing $10 \mu \mathrm{g}$ of myelin basic protein and $40 \mu \mathrm{M}$ [g-32P] ATP (1 $\mu \mathrm{Ci})$, as described previously (Visse et al., 2003). The kinase reaction was allowed to proceed at room temperature for $5 \mathrm{~min}$ and stopped by the addition of Laemmli's SDS sample buffer (Parra et al., 1998). Reaction products were separated by $12 \%$ SDSPAGE.

Assay of JNK-1 and p38 Activity: Cells were incubated in the absence of serum for $16 \mathrm{~h}$ and then treated with various materials. They were then washed twice with PBS and lysed in ice-cold lysis buffer (20 mM HEPES, pH 7.4, $150 \mathrm{mM} \mathrm{NaCl}$, $1 \%$ Triton $\mathrm{X}-100,1.5 \mathrm{mM} \mathrm{MgCl} 2,1 \mathrm{mM}$ EDTA, $1 \mathrm{mM}$ EGTA, $2.5 \mathrm{mM}$ sodium pyrophosphate, $1 \mathrm{mM}$ beta-glycerol phosphate, $1 \mathrm{mM}$ sodium orthovanadate, 1 $\mu \mathrm{g} / \mathrm{ml}$ leupeptin and $1 \mathrm{mM}$ phenylmethylsulfonyl fluoride). The extracts were centrifuged to remove cellular debris, and the protein content of the supernatants was determined using the BioRad protein assay reagent. $100 \mu \mathrm{g}$ of protein from the lysate samples was incubated at $4^{\circ} \mathrm{C}$ over night with the $\mathrm{N}$ terminal c-Jun (1-79) and ATF-2glutathione $\mathrm{S}$-transferase fusion protein bound to glutathione-Sepharose beads in order to selectively precipitate JNK-1 and p38 from cell lysates. Next, the beads were washed to remove non-specifically bound proteins. Then, the kinase reaction was carried out in the presence of cold ATP, and samples were resolved on $12 \%$ SDS-gel electrophoresis followed by Western blotting with phosphospecific c-Jun and p38 antibodies. This antibody specifically recognizes JNK-1-induced phosphorylation of c-Jun at Ser63, a site important for c- 
Jun-dependent transcriptional activity (Visse et al., 2003).

\section{RESULTS}

EGF and cisplatin activates JNK-1 pathway in prostate carcinoma cell lines.

C-jun-NH2 kinases (JNK) are among the UV-activated protein kinases that play an important role in cellular stress response via the phosphorylation of c-jun, ATF2 and p53. Activation of JNK-1 by UV irradiation requires cooperation between membrane and nuclear components, including DNA lesions per se. To determine if EGF and cisplatin activate JNK/SAP pathway in LNCaP, DU145, Kiras-267B1 and PC-3 cells, we treated quiescent cells, maintained in $0.5 \% \mathrm{FBS}$, with either $50 \mathrm{nM}$ rhEGF, $300 \mu \mathrm{g} / \mathrm{ml}$ cisplatin or $100 \mathrm{~J} / \mathrm{m}^{2} \mathrm{UV}$ (as control). JNK-1 activity was measured 1 hour after treatments, as described in Materials and Methods. Results showed that addition of rhEGF and cisplatin activated JNK-1 activity, though to different extents, in quiescent cell lines LNCaP, DU145,
Kiras-267B1 and PC-3 (Figure 1). UV treatment had a significantly higher effect on JNK-1 activity in these cells.

The serine/threonine phosphatase PP4 is expressed in various tumor cell lines and activates JNK-1 in a dose-dependent manner.

Protein phosphatase 4 (PP4) is a novel, ubiquitously expressed protein phosphatase that is structurally related to protein phosphatase 2A (PP2A). PP2A acts as tumor suppressor that it is involved in human breast carcinogenesis and contains a binding domain of okadaic acid, a tumor promoter. The cellular functions of PP4 are currently unknown, however as it localizes predominantly to chromosomes, a role during microtubule nucleation has been suggested (Zhou et al., 2002). We wished to ascertain the levels of endogenous PP4 in several cell lines grown in media containing different concentrations of serum and when treated with TNF or UV radiation as control. As a result, we found that PP4 was induced constitutively in distinct tumor cell lines independently of each treatment (Figure $2 \mathrm{~A}$ ).

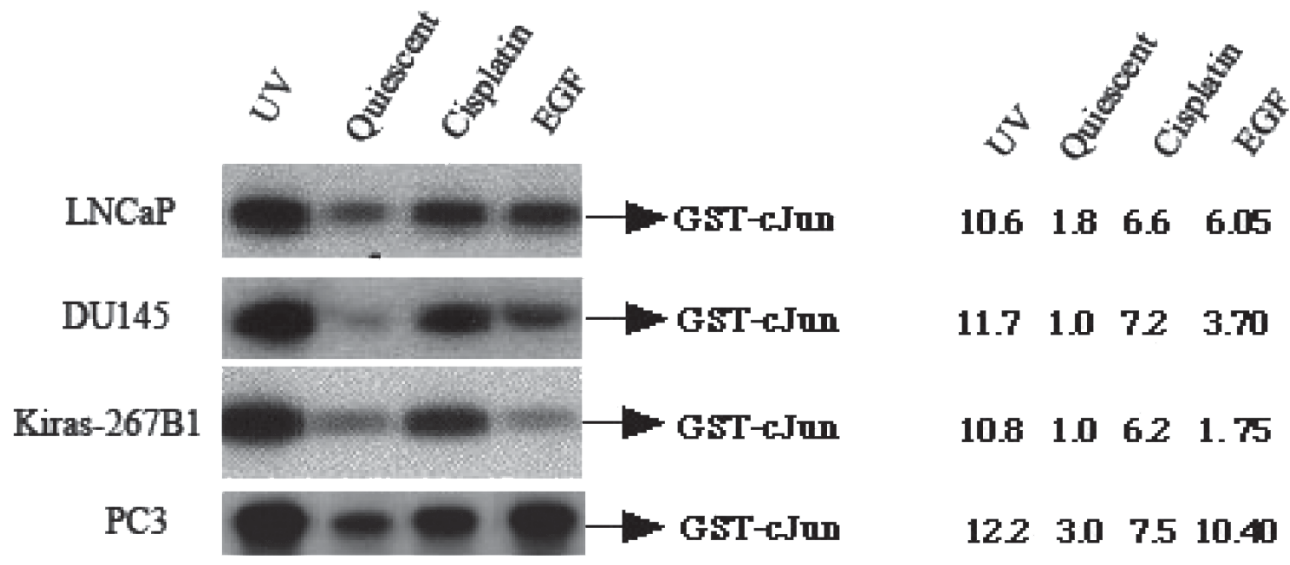

Figure 1. JNK-1 activity in human prostate carcinoma cells.

To determine if EGF or cisplatin activates JNK/SAP pathway in LNCaP, DU145, Kiras-267B1 and PC-3 cells, all grown in $0.5 \%$ FBS, each cell line was treated with rhEGF $10 \mathrm{nM}$ or Cisplatin 300 $(\mathrm{ug} / \mathrm{ml})$, or $100 \mathrm{~J} / \mathrm{m} 2 \mathrm{UV}$ radiation as control. JNK-1 activity was examined one hour after treatment, by immunocomplex kinase assay measuring the phosphorylation of GST-cJun (1-79). Numbers on the right indicate relative amounts of JNK-1 activity obtained for each treatment, compared to levels of JNK-1 activity obtained in quiescent DU145 cells. EGF and cisplatin induced JNK-1 activation, compared to the quiescent state of prostate cells, although at lower levels than UV treatment. 


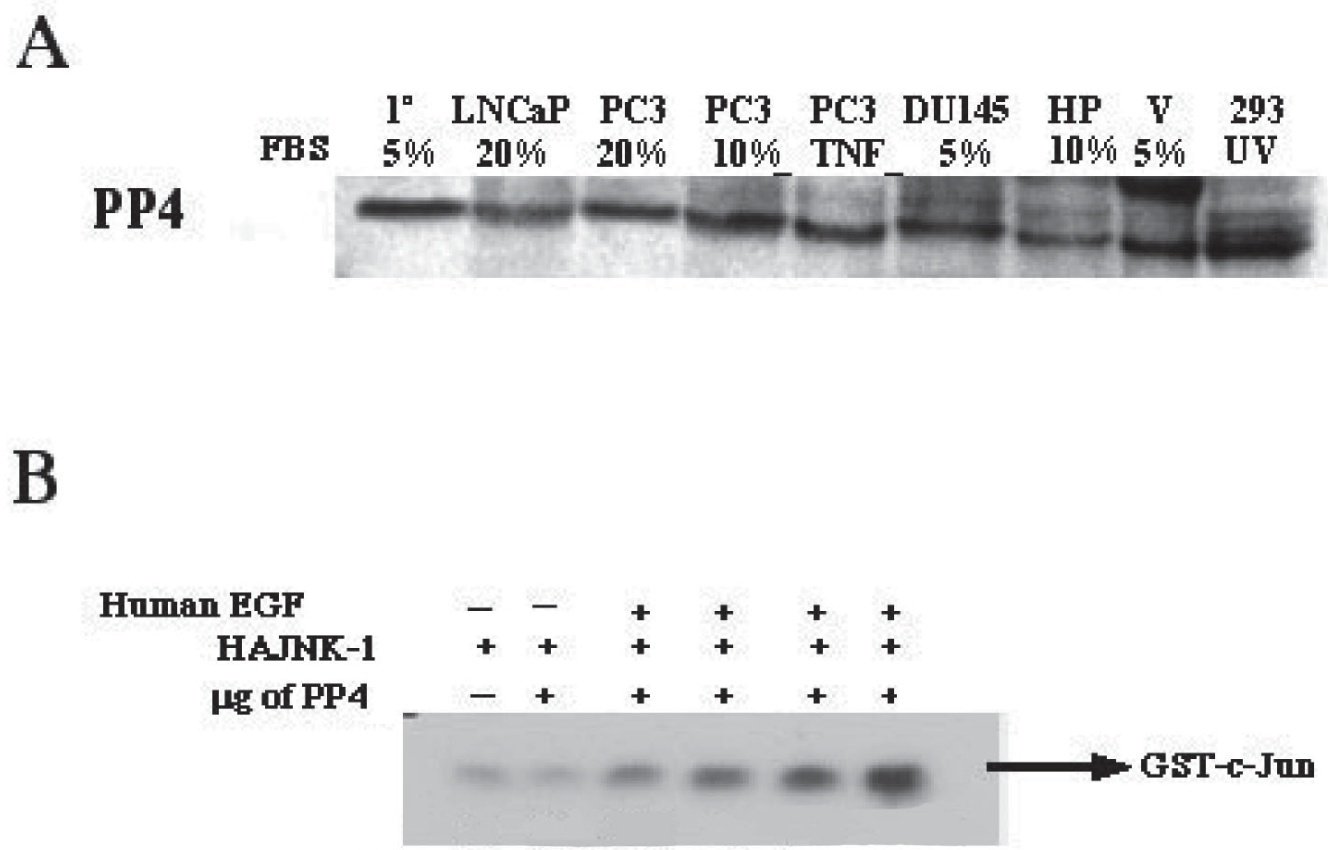

Figure 2. Expression of PP4 in prostate cancer derived cell lines. (Panel A) Western-blot analysis of PP4 in prostate derived primary cells $\left(1^{*}\right)$ as well as prostatic cell lines LNCaP, PC3, DU145 and Hyperplasic Prostatic (HP) and African green monkey kidney Vero cells (V), treated with different serum concentrations or TNF (PC3 line) to induce PP4. 293 cells treated with UV radiation were used as control for PP4 induction. PP4 is induced at different levels in these cells.

The kinase activity of JNK-1 augments in a dose-dependent manner, according to the concentration of PP4 DNA. (Panel B) PC3 cells transfected with HAJNK-1, to enhance the signal to noise ratio of JNK-1 activity, were co-transfected with increasing amounts of PP4 encoding plasmid. Cell lysate were prepared at $48 \mathrm{~h}$ post-transfection and HA-JNK-1 was immunoprecipitated with an anti-HA antibody (12CA5) and its kinase activity assayed using GST-cJun (1-79) as a substrate, as described in Materials and Methods. One of three similar experiments is shown.

To determine whether the activation of JNK-1 is a function of PP4 concentration, we examined JNK-1 activity after cotransfection with a PP4-encoding plasmid (Figure 2 B). PC-3 cells were cotransfected with $3 \mathrm{ug}$ of plasmid encoding HA-JNK-1, to increase the signal to noise ratio, and different amounts of plasmid encoding PP4. The transfected cells were treated with rhEGF $(50 \mathrm{mM})$ after 24 hours. JNK-1 activation was examined by immunoprecipitation of HA-JNK-1 using the anti-HA antibody (12CA5), followed by in vitro kinase assays using GST-cJun (1-79) as substrate. JNK-1 activity was seen at low PP4 levels (untransfected cells, lane 1) and increased according to the increase in PP4 expression (lanes 2-6).

\section{PP4 specifically activates JNK-1}

To demonstrate that PP4 activates specifically JNK-1, we compared its effect over JNK-1 activity with other members of the MAPK family such as p38 and ERK. To this end we co-transfected different amounts of HA-JNK-1 combined with an established amount of PP4 or empty vector into PC3 cells. Cell lysates were prepared at $24 \mathrm{~h}$ after transfection and HA-JNK-1 was immunoprecipitated with an anti-HA antibody (12CA5). JNK-1 activity was examined by immunocomplex kinase using GST-c-Jun (1-79) as substrate (Figure 3A). To elucidate the specificity of the effect of PP4 on JNK-1 activity, PC-3 cells were co-transfected with PP4 and p38 (Figure 
3B) or ERK-2 (Figure 3C). MKK6, a kinase upstream of p38, and PKC-z, which phophorylate ERK-2, were used as positive control for p38 and ERK-2 respectively. In both cases, kinases were immunoprecipitated and assayed over substrates GST-ATF2 for p38 and Myelin Basic Protein (MBP) for ERK-2. While PP4 increased JNK-1 activity (Figure 3A), it had no effects on p38 (Figure 3B) and ERK-2 activities (Figure 3C). MKK6 and PKC-z used as positive controls increased activities of p38 and ERK-2 respectively. These results indicate that PP4 is a specific positive regulator for JNK-1 pathway, but not for p38 and ERK-2.

PP4 acts as a positive regulator of JNK-1 in prostate cancer cell lines $P C-3$ and LNCAP

To understand the mechanism of activation of JNK-1 mediated by PP4, we sought to test other members of the JNK $1 / 2$ activating pathway that could be regulating JNK-1. One possibility is that PP4 could be inhibiting a putative JNK-1 phosphatase that specifically inhibits JNK-1. This putative JNK-1 phosphatase may be activated by phosphorylation and hence inactivated by de-phosphorylation. Only one phosphatase specific for JNK-1 has been described: M3/ 6, which has been implicated in the inhibition of JNK-1 (Muda et al., 1996; Chen et al., 2001). To determine whether there is a causal relationship between JNK-1 activity and PP4 after EGF stimulation, determined amounts of HA-JNK-1, combined with an established amount of PP4 or M/36 were co-transfected into PC-3 and LNCaP cells. Empty vector was used to normalize the amount of transfected DNA. Cell lysates were prepared at $24 \mathrm{~h}$ posttransfection, and HA-JNK-1 was assayed by immunocomplex formation as above. The results showed that over-expression of the

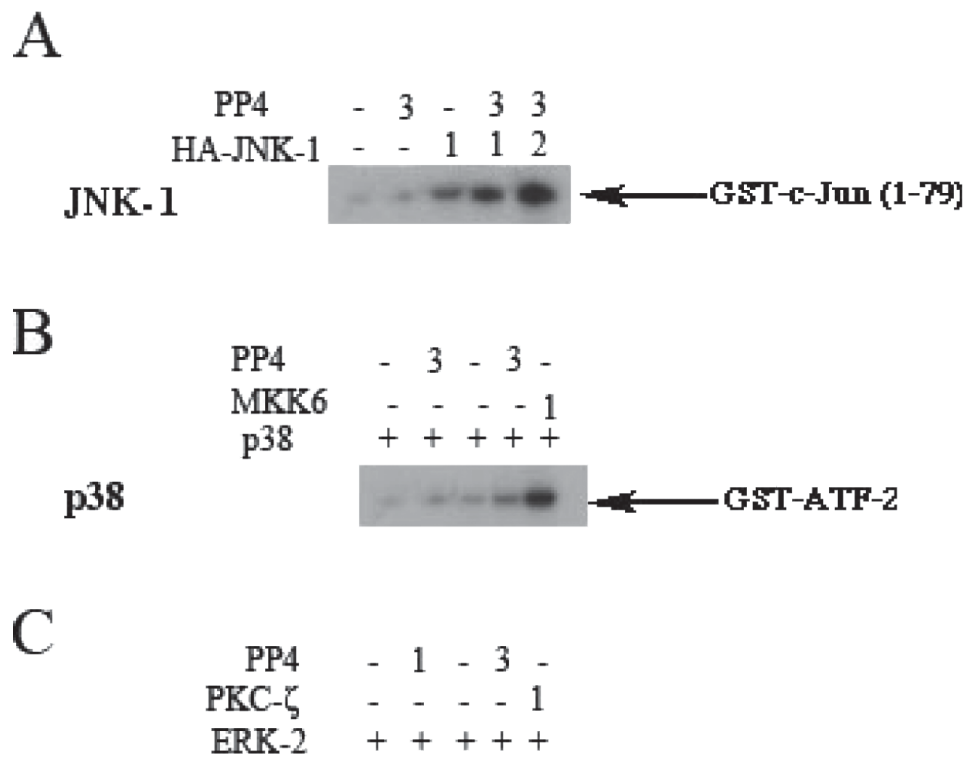

ERK-2

HBP

Figure 3. PP4 specifically activates JNK-1 but not p38 and ERK. Different amounts of HAJNK-1 and PP4 plasmids were co-transfected into PC-3 cells. Cell lysates were prepared at $48 \mathrm{~h}$ post-transfection and JNK-1 activity was assayed as described (Panel A). In Panels B and C, cotransfection of p38 and ERK2 with different amounts of PP4 into PC-3 cells are shown. MKK-6 and PKC- $\zeta$ were used as a positive control for p38 and ERK-2, respectively. The p38 and ERK2 activities were determined by immunocomplex kinase assays using GST-ATF2 and MBP as substrates respectively. PP4 was unable to induce p38 and ERK2 activities. One of two similar experiments is shown. 
phosphatase M3/6 can, at least, decrease partially the activity of JNK-1, which supports the notion that M3/6 is a phosphatase specific for JNK-1 (Muda et al., 1996). On the other hand, co-transfection of JNK-1 and PP4 strongly increase the activity of JNK-1, which suggests that PP4 acts as a positive activator of JNK-1. Further studies through co-transfection of M3/6 and PP4 in both PC-3 and LNCaP prostate carcinoma cell lines demonstrated that M3/6 could not decrease the activity of JNK-1 in presence of PP4. Instead, we observed an additional increase of JNK-1 activity compared with transfection with PP4 alone. These results further substantiated the notion that PP4 targets a JNK-1-activating phosphatase and strongly supported the notion that of the specificity of this phosphatase in the regulation of JNK pathway (Figure 4A and 4B). The levels of expression of JNK-1, PP4 and $\mathrm{M} 3 / 6$ in these experiments, assayed by Western blots of protein extracts of the transfected PC-3 cell line, were according to the range expected (Figure 4C). JNK-2 was also distinguished by the JNK-1 antibody and thus serves as an internal control for protein loading.
A
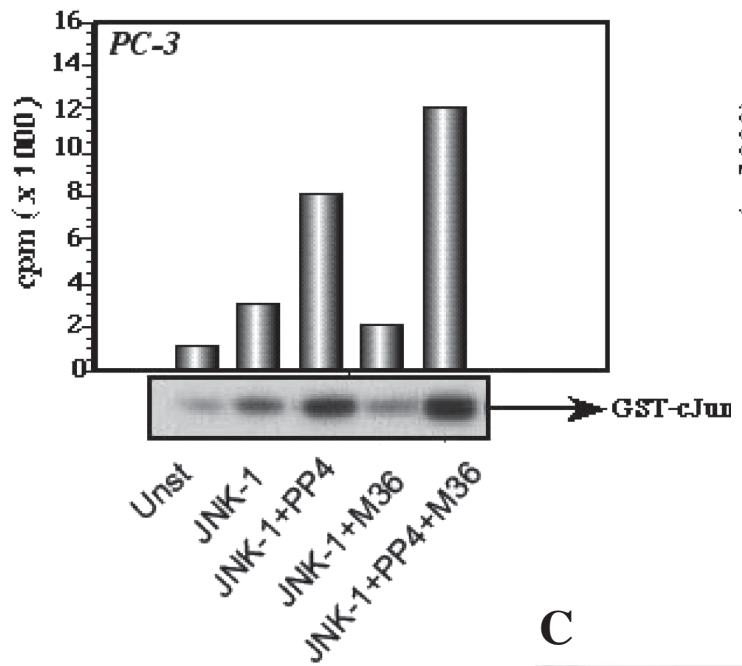

B

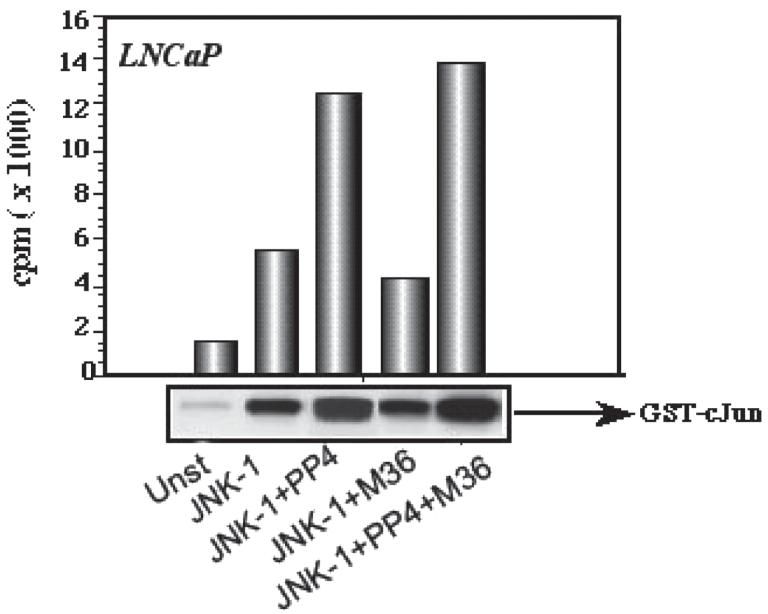

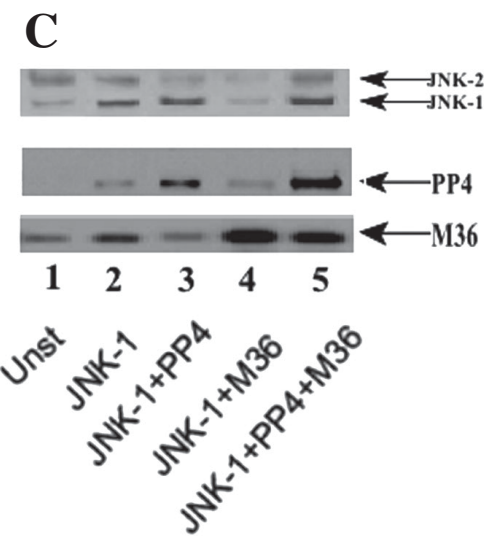

Figure 4. PP4 induced down-regulation of a JNK-1 phosphatase M3/6. PC-3 and LNCaP prostate carcinoma cell lines were co-transfected with JNK-1 and PP4 or M3/6, or with all three vectors. Transfected cells were treated with EGF $50 \mathrm{ng} / \mathrm{ml}$. Induction of the JNK-1 kinase activity was examined by immunocomplex kinase assay as described. One of three similar experiments is shown. Representative blots show comparative protein levels of total JNK-1, JNK-2, PP4 and M3/6 proteins in the PC-3 Prostate cell line. Lane 1, un-transfected cell line; Lane 2, cells transfected with JNK-1; Lane 3, cells transfected with both JNK-1 and PP4; Lane 4, cells transfected with both JNK-1 and M3/6; and Lane 5, protein levels from cells transfected with JNK-1, PP4 and M3/6 (Figure 4C). 


\section{AP-1 functional activity}

Expression of the trans-dominant inhibitor of c-Jun, cJun-Ala $(63,73)$ blocks the effect of EGF transcriptional activity.

To show that the activation of the JNK-1 pathway activates promoters bearing AP-1 response elements, transient transfection studies were carried out using a reporter construct bearing the consensus or classic AP-1 site repeated in tandem (6x) driving expression of a Luciferase reporter. Expression of this reporter in PC-3 (Figure
5A) and LNCaP (Figure 5B) cells leads to little activation, whereas EGF treatment enhances expression of this reporter. Coexpression with a known activator of the JNK-1 pathway, an expression vector for the wild-type c-Jun, leads to substantial activation of the $6 \mathrm{x}$ AP-1 reporter. Addition of an expression vector for dn-c-Jun - c-Jun (Ala 63,73) - but not wild-type c-Jun leads to a readily detectable inhibition in both $\mathrm{PC}-3$ and $\mathrm{LNCaP}$ prostate cell lines. Since JNK-1 also activates Elk-1, leading to increased c-Fos, both AP-1 and ATF/ CREB-dependent transcription is increased
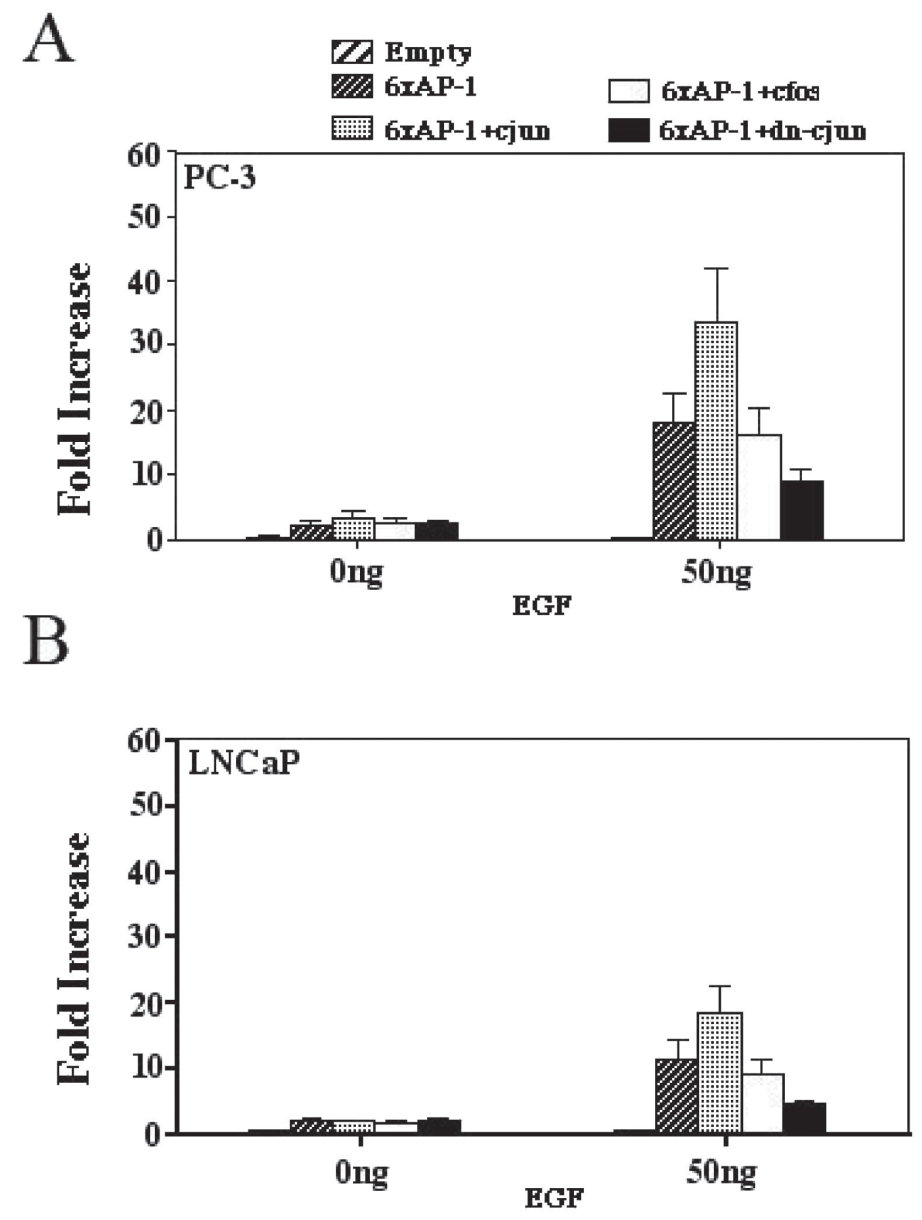

Figure 5. Inhibition of AP-1-dependent transcription, induced by EGF-stimulation, by a dominant negative form of c-Jun, dn-c-Jun. The reporter, which contains 6 AP-1 response elements in tandem directing expression of the Luciferase gene, was transfected into PC-3 cells either alone or in combination with c-Jun (dotted bars), c-Fos (open bars) and, dn-c-Jun (filled bars). One set of transfections was treated 24 hours later with $50 \mathrm{ng} / \mathrm{ml} \mathrm{rhEGF}$. The graph shows Luciferase activity compared to controls with reporter lacking AP-1 sites. The AP-1 reporter requires an activated c-Jun and is, therefore, activated by increased expression of c-Jun. The reporters are inhibited by dn-c-Jun. 
by c-Jun and inhibited by dn-cJun. However, a marginal decrease in the Luciferase activity was observed after the addition of the c-fos expression plasmid with respect to reporter alone, under EGF treatment. The observations also suggest a means of determining whether preferential activation of AP-1 occurs in human tumor cells upon treatment with growth factor agents.

\section{AP-1 and EGR-1 are rapidly induced in prostate cell lines $P C-3$ and LNCaP.}

To exclude the possibility of a differential expression of transcription factors AP-1 and EGR-1 in PC-3 (p53 deficient and androgen resistant) and LNCaP (p53 normal and androgen sensitive) cells after EGF stimulation, because this could alter our results according to cell type, Electrophoretic Mobility Shift Assay (EMSA) was used to analyze the capacity of DNA binding by AP-1 and EGR-1. Nuclear extracts from PC-3 and LNCaP were obtained at a given times after in vitro EGF treatment $(50 \mathrm{nM})$ and incubated with radioactive-labeled oligonucleotides bearing recognition sites for either $\mathrm{AP}-1$ (Figure 6A and 6B) or EGR-1 (Figures 6C and $6 \mathrm{D})$. AP-1 and EGR-1 were found to be induced after 30 minutes, increased to maximum at 1 hour in both $\mathrm{PC}-3$ and LNCaP prostate cell lines. The nucleotides did not form a DNA-protein complex in absence of nuclear proteins in the reaction mixture (Figure 6, lane 1 in A, B, C and D). Binding of AP-1 (Figures 6 A, B) and EGR1 (Figures $6 \mathrm{C}, \mathrm{D}$ ) to the consensus oligonucleotides sequence increased dramatically when the cells had been treated with $50 \mathrm{nM}$ EGF for $30 \mathrm{~min}$ (Figure 6, lane 3 in A, B, C and D). A further increase was observed after 60 minutes incubation (Figure 6, lane 4 in A, B). In a further verification of the specificity of the complex bound to AP-1 and EGR-1 sequences, a 100-fold (Figure 6, lane 5 for A, B , C , D) excess of unlabelled AP-1 and EGR-1 (cold oligo) oligonucleotides efficiently competed in the complex formation with the labeled probe. Addition of a 100-fold molar excess of unrelated oligonucleotide, Sp1 consensus, had no effect on the band intensity of these complexes (Figure 6, lane 6 in A, B, C, and $D)$. These results indicate that the binding of transcription factors AP-1 and EGR-1 to their cognate sequence motifs is inducible and specific.

\section{DISCUSSION}

The objective of this study is to determine if the phosphatase PP4 regulates the activity of JNK-1 in human prostate cancer lines and the effect of JNK-1 over early growth factors, like c-Jun and EGR-1. We analyzed different activators of JNK-1 pathways by co-transfection experiments, using two prostate carcinoma cell lines: PC-3 (hormone-independent) and LNCaP (hormone-sensitive). These studies showed that the PP4 pathway might function to mediate the transforming effects of EGF and cisplatin in the induction of $\mathrm{JNK}-1$ in the PC-3 and LNCaP treated prostate cancer cell lines and that both the ERK/MAPK and JNK-1 pathways mediate the action of EGF and cisplatin in our in vitro model. The two agents showed similar effects on the activation of the kinases and stress signaling pathways. Once activated, the JNK/SAPK pathway is known to initiate regulatory events, which correspond closely to the regulation of enzymes associated with DNA repair. Thus, in order to study these findings, we explored a novel mechanism by which JNK-1 pathway is regulated by $\mathrm{PP} 4$, a novel serine/threonine protein phosphatase, constitutively expressed in prostate cancer cells (Brewis, 1993; Hanada et al., 1998; Cohen \& Cohen, 1989). Accordingly, we found that all prostate cancer cell lines examined expressed the phosphatase PP4 constitutively. We also found that overexpression of PP4 increased JNK-1 activity in both PC-3 and LNCaP prostate cancer cell lines when treated with EGF. This result is in contrast to a previous report, which used an immortalized cell line model, actually the HEK293 cell line, to study the role of PP4 (Zhou et al., 2002). Thus, we are the first to show that PP4 has 


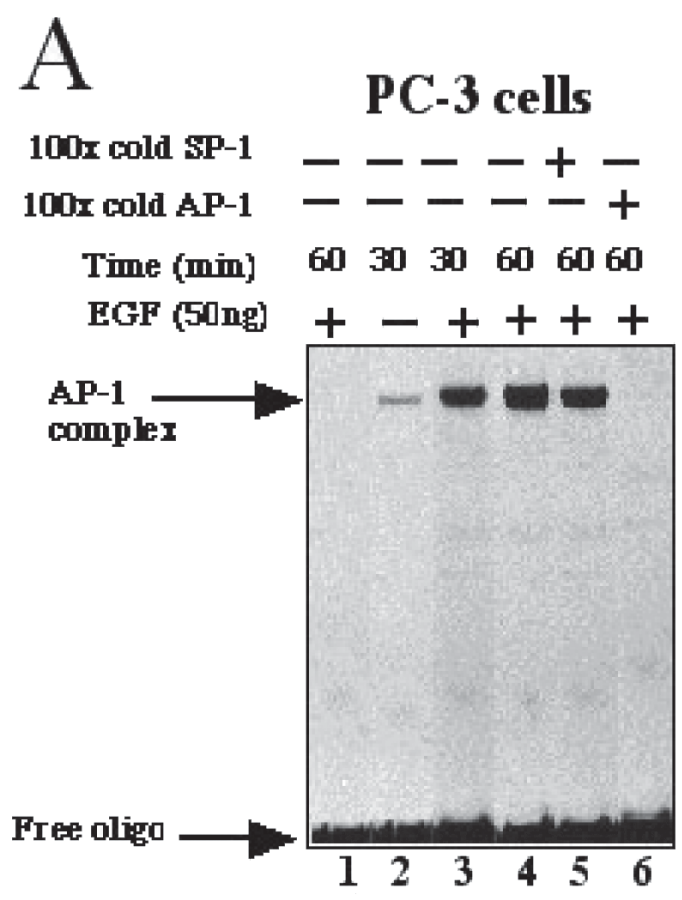

\section{PC-3 cells}

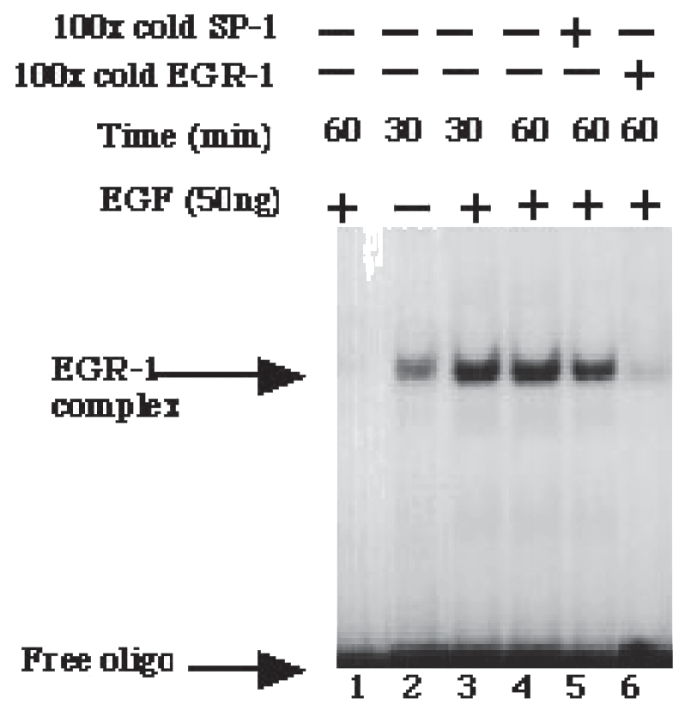

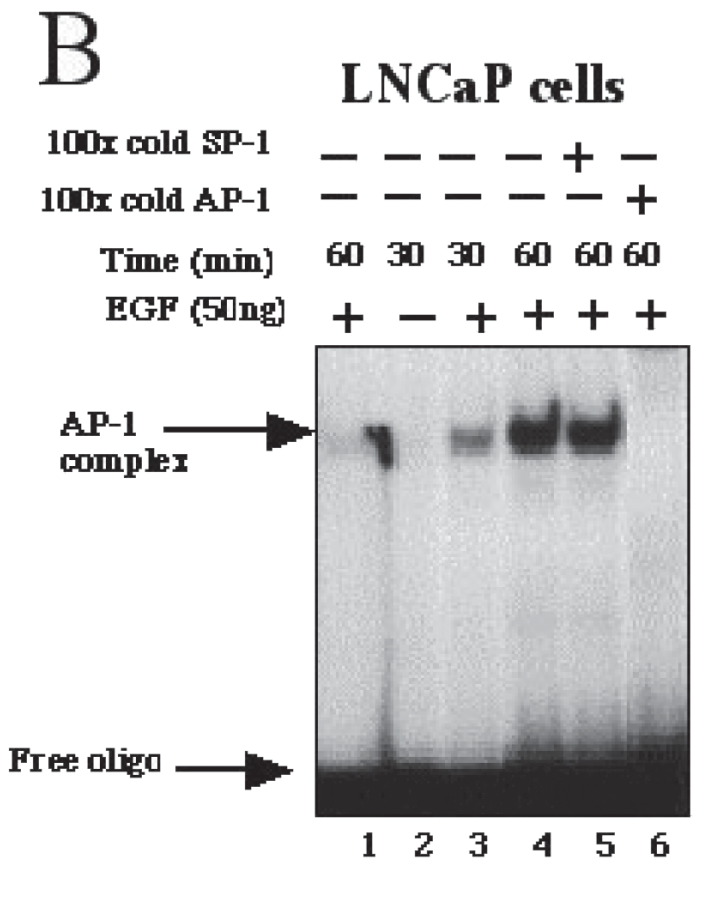

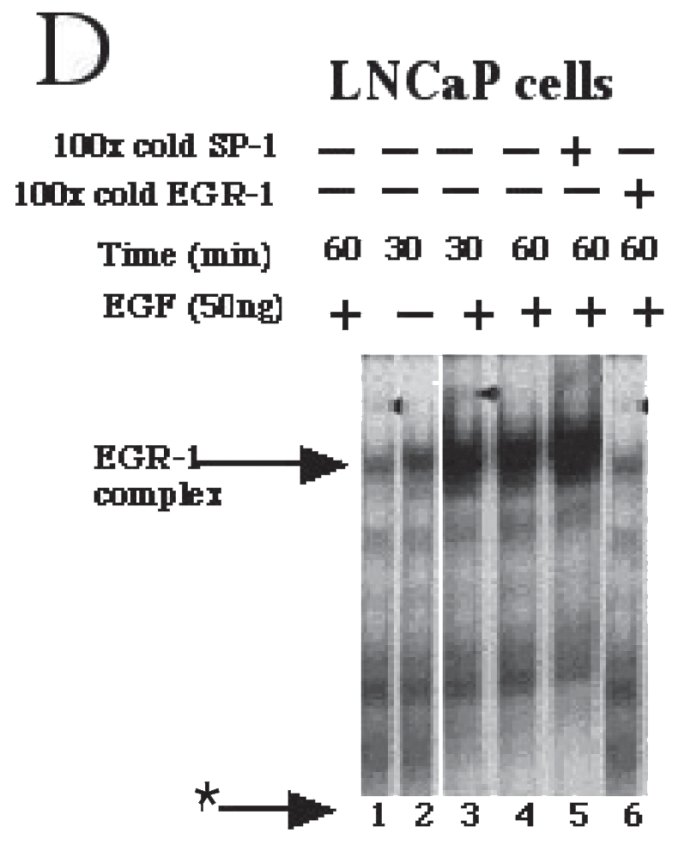

Figure 6. Expression of AP-1 and EGR-1 in PC-3 and LNCaP prostate carcinoma cell lines. Cells were transfected with PP4 and JNK-1 and treated with rhEGF for 1 hour. Nuclear protein extracts were prepared as described and used for gel shift analysis with ${ }^{32} \mathrm{P}$-labeled oligonucleotides specific for AP-1 (Panels A and B) and EGR-1 (Panels C and D). Cross competition of AP-1 and EGR-1 vs. SP-1 was as follows: nuclear extract from PC-3 and LNCaP prostate cancer cell lines were incubated with 100 -fold molar excess of unlabeled competitors for 30 min before addition of labeled DNA. * Indicate were the free oligonucleotide was ran out of the gel. One of three similar experiments is shown. 
a role in the activation of JNK-1 in prostate carcinoma cell lines, suggesting a role of this phosphatase in the activation of JNK-1 in vivo. Contrary to the stated hypothesis that PP4 is acting on an upstream JNK-1 activating protein kinase pathway, we proposed the possibility that the dephosphorylation of an upstream phosphatase is involved in keeping JNK-1 active in prostate carcinoma cell lines.

In this case, our studies showed that PP4 specifically activates JNK-1 but has no effect over p38 and ERK. PP4 is a novel, ubiquitously and highly conserved serine/ threonine protein phosphatase that is structurally related to protein phosphatase 2 A (PP2A) (with 65\% amino acid sequence identity) and contains a binding domain of okadaic acid, a tumor promoter (Kloeker et al., 2003). We demonstrated not only that the PP4 is consistently expressed in LNCaP and $\mathrm{PC}-3$ prostate cell lines but also that PP4 acts as a positive regulator of the JNK1 MAP kinase. We also showed that PP4 synergies with EGF to activate JNK-1, while the over-expression of the dual specificity phosphatase M3/6 showed no effect over JNK-1. However, when the cells were co-transfected together with PP4 and $\mathrm{M} 3 / 6$, we found a minor inhibitory effect on induced JNK-1 activation. A hallmark of these growth regulatory signal pathways is the reversible phosphorylation of many of their components, which results in the activation or inhibition of the respective substrate functions (Schonthal, 2001; Bintruy et al., 1991). Indeed, it has been demonstrated that many (proto)-oncogenic factors contain kinase activity that can induce tumorogenic transformation when inappropriately augmented or mutated (Rosette and Karin, 1996). On the other hand, the exact role that protein phosphatases are playing in these events is much less clear. However, the finding that some of the enzymes are crucial components of pathways that regulate cell growth and proliferation has brought them to the forefront of cancer research (Pages et al., 1993; Brunet et al., 1994). So far, only a few phosphatases have been directly implicated in the etiology of tumors. For example, the dual specificity protein phosphatase PTEN exhibits many characteristics of a typical tumor suppressor and is frequently found mutated or deleted in advance prostate cancer (Yen et al., 1997; Vliestra et al., 1998). However, little is known about the correlation between phosphatases, kinases and the early nuclear factors, which are the target of these pathways. The fact that the expression of EGR-1 and AP-1 is increased in PC-3 and LNCaP suggests that the transformed cells may trigger anti-apoptotic changes, favoring proliferation, cell transformation and the expression of components of the DNA-reparation machinery. It is postulated that JNK-1 is specifically required for growth of certain human tumor cells such as prostate carcinoma (Potapova et al., 1997). However, it is also known that JNK1 is required for the induction of apoptosis and that the specific stimulation of the pathway by expression of constitutively active components such as MEKK1 or downstream kinases leads to apoptosis (Xu et al., 1996). In addition, several reports have also demonstrated an important role for stress-signaling molecules such as MEKK-1 in regulating cisplatin sensitivity. MEKK-1 becomes phosphorylated and is subsequently cleaved by caspase- 3 upon treatment with cisplatin (Widmann et al., 1998). It is also known that JNK-1 activity is strongly induced in response to a variety of DNA-damaging treatments such as UV irradiation (Adler et al., 1995). These results, when combined with the above studies, indicate that transformation by the JNK-1 pathway may require an additional but unknown affecter(s) of the Ras/MAP kinase pathway, which are not themselves transforming. Additional studies have demonstrated in several human tumor cell lines, especially in prostate carcinoma, that JNK-1 is required for DNA repairing of cisplatin-induced lesions and that EGFstimulated authocrine growth of certain lung carcinoma cells is mediated by JNK-1 and not ERK (Potapova et al., 1997; Bost et al., 1997). However, apoptosis induced by Epidermal Growth Factor (EGF) requires JNK-1. EGF stimulation has been implicated in the proliferative response of hepatocytes under both in vitro and in vivo 
conditions (Bost et al., 1997). Here, we also demonstrated that treatment of prostate cells lines with EGF results in increased activation of JNK-1. These changes were also associated with an up-regulation of EGR-1 and AP-1 transcription and protein expression in both $\mathrm{PC}-3$ and $\mathrm{LNCaP}$ prostate cell lines. These studies suggested that JNK-1 plays an important role in the regulation of DNA repair and DNA synthesis in human tumor cells.

Another way of studying the activity of JNK-1 is by using a c-Jun dominant negative vector (Bost et al., 1997). If dn-c-Jun was working through a dominant negative mechanism, it would be expected to have little effect on JNK-1 enzyme activity or on the level of phosphorylated c-Jun, but would inhibit the transcriptional activity of activated c-Jun owing to the formation of non-phosphorylated dn-c-Jun/c-Fos and dnc-Jun/ATF-2 heterodimers. Since JNK-1 also activates ELK-1 leading to increased c-Fos, both AP-1 and ATF/CREB-dependent transcription would be increased by c-Jun and inhibited by dn-c-Jun. However, in our results we found no increase in the Luciferase activity after the addition of the c-Fos expression plasmid. These observations also suggest a means of determining whether preferential activation of AP-1 occurs in human tumor cells upon treatment with growth factor agents. Finally, based on our findings, we propose that the up-regulation of JNK-1 and PP4, resulting from EGF and cisplatin pre-treatment in prostate carcinoma cell lines, results in the establishment of an anti-apoptotic state, as has been previously published (Bost et al., 1997). This accounts for the decrease in apoptosis observed by the cells treated with cisplatin (Bost et al., 1997). Together these studies support the existence of a causative relationship between DNA damage and activation of JNK/SAPK. It appears that PP4 acts in synergy with signals induced by cisplatin and EGF, triggering an overexpression of JNK-1 that would eventually lead to a greater anti-apoptotic response by keeping low the activity of one specific JNK-1 phosphatase and by inducing activation of genes involved in DNA damage response pathway.

\section{ACKNOWLEDGEMENTS}

To Dr. Roger J. Davis for providing us with the GST-c-Jun (1-79) and GST-ATF-2. MKK6-expression plasmid was provided by Dr. Eduardo Rodríguez (Rudbeck

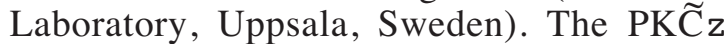
expression plasmid was a gift from Dr. Jose Arteaga (Karolinska Institute, Sweden). This work was supported by the Chilean National Science Foundation FONDECYT regular grant award 1020943.

\section{REFERENCES}

ADAMSON ED, WILEY LM (1997) The EGFR gene family in embryonic cell activities. Curr Top Dev Biol 34: 71-120

ADLER Y, FUCHS SY, KIM J, KRAFT A, KING MP, PELLING J, RONAI Z (1995) Jun-NH2-terminal kinase activation mediated by UV-induced DNA lesions in melanoma and fibroblast cells. Cell Growth Differ 6: 1437-1446

AHMED MM, CHENDIL D, LELE S, VENKATASUBBARAO K, DEY S, RITTER M, ROWLAND RG, MOHIUDDIN M (2001) Early growth response-1 gene: Potential radiation response gene marker in prostate cancer. Am J Clin Oncol 24: 500-505

BARON V, DUSS S, RHIM J, MERCOLA D (2003) Antisense to the early growth response-1 gene (EGR-1) inhibits prostate tumor development in TRAMP mice. Ann NY Acad Sci 1002: 197-216

BINTRUY B, SMEAL T, KARIN M (1991) Ha-ras augments c-Jun activity and stimulates phosphorylation of its activation domain. Nature 351: 122-127

BLENIS J (1993) Signal transduction via the MAP kinase proceed at your own RISK. Proc Natl Acad Sci, USA 90: 5889-5892

BOCCO JL, BAHR A, GOETZ J, HAUSS C, KALLUNKI $\mathrm{T}$, KEDINGER C, CHATTON B (1996) In vivo association of ATFa with JNK/SAP kinase activities. Oncogene 12: 1971-1980

BOST F, DEAN N, MCKAY R, MERCOLA D (1997) Activation of the Jun Kinase/Stress-Activated Protein Kinase Pathway is Required for EGF Autocrine Stimulated Growth of Human A549 Lung Carcinoma Cells. J Biol Chem 272: 33422-33429

BREWIS, ND (1993) PPX, a novel protein serine/threonine phosphatase localized to centrosomes. EMBO J 12: 987-996

BRUNET A, PAGES G, POUYSSEGUR J (1994) Constitutively active mutants of MAP kinase-kinase (MEK1) induce growth factor-relaxation and oncogenicity when expressed in fibroblasts. Oncogene 9: $3379-3387$

CHEN YR, SHRIVASTAVA A, TAN TH (2001) Downregulation of the c-Jun $\mathrm{N}$-terminal kinase (JNK) phosphatase M3/6 and activation of JNK-1 by hydrogen peroxide and pyrrolidine dithiocarbamate. Oncogene 20: 367-374

COBB MH. GOLDSMITH J (1995) How MAP kinases are regulated. J Biol Chem 270: 14843-14846

COHEN P, CHEN PTW (1989) Protein phosphatases come of age. J Biol Chem 264: 21435-38 
COHEN PT (1990) Protein serine/phosphatases: An expanding family. FEBS let 268: 355-59

COHEN PT (1997) Novel protein serine/threonine phosphatase: Variety is the spice of life. Trends Biochem Sci 22: 245-251

DERIJARD B, HIBI M, WU I-H, BARRETT T, SU B, DENG T, KARIN M, DAVIS RJ (1994) JNK1, a protein kinase stimulated by UV light and Ha-Ras that binds and phosphorylates the c-Jun activation domain. Cell 76: 1025-1037

FANGER GR (1997) MEKKs, GCKs, MLKs, PAKs, TAKs, and tpls: Upstream regulators of the c-Jun amino terminal kinases. Curr Opin Genet Dev 7: 67-74

FOLTZ IN, GERL RE, WIELER JS, LUCKACH M, SALMON RA, SCHRADER JW (1998) Human mitogen-activated protein kinase kinase 7 (MKK7) is a highly conserved c-Jun N-terminal kinase/stressactivated protein kinase (JNK/SAPK) activated by environmental stresses and physiological stimuli. J Biol Chem 273: 9344-9351

GROVER-BARDWICK A, ADAMSON E, MERCOLA D (1994) Transformation-specific pattern of phosphorylation of c-Jun, Jun-B, Jun-D and EGR-1 in V-sis transformed cells. Carcinogenesis 15: 1667-1674

GUAN KL, BROYLES SS, DIXON JE (1991) A Tyr/Ser protein phosphatase encoded by vaccinia virus. Nature 350: 359-362

GUPTA S, CAMPBELL D, DERIJARD B, DAVIS RJ (1995) Transcription factor ATF2 regulation by the JNK-1 signal transduction pathway. Science 267: 389393

HANADA M, KOBAYASHI T, OHNISHI M, IKEDA S, WANG H, KATSURA K, YANAGAWA Y, KANAMARU A, TAMURA S (1998) Selective suppression of stress-activated protein kinase pathway by protein phosphatase, ICE/CED-3 proteases, intracellular acidification, and DNA fragmentation in apoptosis. Exp Cell Res 230: 22-27

HANEDA M, SUGIMOTO T, KIKKAWA R (1999) Mitogen-activates protein kinase phosphatase: A negative regulator of the mitogen protein kinase cascade. Eur J Pharmacol 365: 1-7

HASHIMOTO K, HIGASHIYAMA S, ASADA $\mathrm{H}$, HASHIMURA E, KOBAYASHI T, SUDO K, NAKAGAWA T, DAMM D, YOSHIKAWA K, TANIGUCHI N (1994) Heparin-binding epidermal growth factor-like growth factor is an authocrine growth factor for human keratinocytes. J Biol Chem 269(31): 20060-20066

HIBI M, LIN A, SMEAL T, MINDEN A, KARIN M (1993) Identification of an oncoprotein- and UV-responsive protein kinase that binds and potentiates the c-Jun activation domain. Genes and Development 7: 2135-2148

IP YT, DAVIS RJ (1998) Signal transduction by the c-Jun N-terminal kinase (JNK) - From inflammation to development. Curr Opin Cell Biol 10: 205-219

JANKNECHT R, ERNST WH, PINGOUD V, NORDHEIM A (1993) Activation of ternary complex factor Elk-1 by MAP kinases. EMBO J 12: 5097-5104

JANKNECHT R, HUNTER T (1997) Convergence of MAP kinase pathways on the ternary complex factor Sap-1a. EMBO J 16: 1620-1627

KARIN, M (1995) The regulation of AP-1 activity by mitogen-activated protein kinases. J Biol Chem 270: 16483-16486

KEETON AB, BORTOFF KD, BENNETT WL, FRANKLIN JL, VENABLE DY, MESSINA JL (2003) Insulin-regulated expression of Egr-1 and Krox 20: dependence on ERK1/2 and interaction with p38 and PI3-kinase pathways. Endocrinology 144: 5402-5410
KEYSE SM (1998) Protein phosphatases and the regulation of MAP kinase activity. Semin Cell Dev Biol 9: 143-152

KLOEKER S, REED R, MCCONNELL JL, CHANG D, TRAN K, WESTPHAL RS, LAW BK, COLBRAN RJ, KAMOUN M, CAMPBELL KS, WADZINSKI BE (2003) Parallel purification of three catalytic subunits of the protein serine/threonine phosphatase $2 \mathrm{~A}$ family $(\mathrm{PP} 2 \mathrm{~A}(\mathrm{C}), \mathrm{PP} 4(\mathrm{C})$, and PP6(C)) and analysis of the interaction of $\mathrm{PP} 2 \mathrm{~A}(\mathrm{C})$ with alpha4 protein. Protein Expr Purif 31: 19-33

MINDEN A, LIN A, SMEAL T, BERIJARD B, COBB M, DAVIS R, KARIN M (1994) C-Jun and N-terminal phosphorylation correlates with activation of the JNK1 subgroup but not the ERK subgroup of mitogenactivated protein kinases. Molec Cell Biol 14: 66836688

MORA GR, OLIVIER KR, CHEVILLE JC, MITCHELL RF JR, LINGLE WL, TINDALL DJ (2004) The cytoskeleton differentially localizes the early growth response gene-1 protein in cancer and benign cells of the prostate. Mol Cancer Res 2: 115-128

MUSTELIN T, VANG T, BOTTINI N (2005) Protein tyrosine phosphatases and the immune response. Nature Reviews Immunology 5: 43-57

MUDA $\mathrm{M}$, THEODOSIOU A, RODRÍGUEZ N, BOSCHERT U, CAMPS M, GILLIERON C, DAVIES K, ARKINSTALL A (1996) The dual specificity phosphatases M3/6 and MKP-3 are highly selective for inactivation of distinct mitogen-activated protein kinases. J B Chem 271: 27205-27208

PAGES G, LENORMAND P, LALLEMAIN G, CHAMBARD JC, MELOCHE S, POUYSSEGUR J (1993) Mitogen-activated protein kinases p42mapk and p44mapk are required for fibroblast proliferation. Proc Natl Acad Sci, USA 90: 8319-8323

PARRA E, VARGA M, HEDLUND G, KALLAND T, DOHLSTEN M (1997) Co-stimulation by B7-1 and LFA-3 target distinct nuclear factors that bind to the Interleukin-2 promoter: B7-1 negatively regulates LFA-3 induced NF-AT DNA binding. Mol Cell Biol 17: $1314-1325$

PARRA E, MCGUIRE K, HEDLUND G, DOHLSTEN M (1998) Overexpression of RelA and c-Jun substitutes for B7-1 costimulation by targeting the CD28RE within the IL-2 promoter. The Journal of Immunology 160: 5374-5385

PIPAON C, CASADO JA, BUEREN JA, FERNÁNDEZLUNA JL (2004) Jun N-terminal kinase activity and early growth-response factor-1 gene expression are down-regulated in Fanconi anemia group A lymphoblasts. Blood 103: 128-132

POTAPOVA O, HAGHIGHI A, BOST F, LIU C, BIRRER MJ, GJERSET R, MERCOLA D (1997) The JNK1 stress-activated protein kinase pathway functions to regulate DNA repair and inhibition of the pathway sensitizes tumor cells to cisplatin. J Biol Chem 272: 14041-14044

ROBINSON MJ, COBB MI (1996) Mitogen-activated protein kinase pathway. Curr Opin Cell Biol 9: 180-196

ROSETTE C, KARIN M (1996) Ultraviolet light and osmotic stress: Activation of the JNK-1 cascade through multiple growth factor and cytokine receptors. Science 274: 1194-1197

SÁNCHEZ I, HUGHES RT, MAYER BJ, YEE K, WOODGETT JR, ZON LI (1994) Role of SAPK/ERK kinase- 1 in the stress-activated pathway regulating transcription factor c-Jun. Nature 372: 794-798

SCHONTHAL AH (2001) Role of serine/threonine protein phosphatase 2 in cancer. Cancer Letters 170: 1-13 
SHIOZAKI K, RUSSELL P (1995) Counteractive roles of protein phosphatase $2 \mathrm{C}$ (PP2C) and a MAP kinase kinase homolog in the osmoregulation of fission yeast. EMBO J 14: 492-502

SMEAL T, BINETRUY B, MERCOLA D, GROVERBARDWICK A, HEIDECKER G, RAPP UR, KARIN M (1992) Oncoprotein-mediated signaling cascade stimulates c-Jun activity by phosphorylation of serines 63 asid 73. Mol Cell Biol 12: 3507-3513

TATEISHI M, ISHIDA T, MITSUDOMI T, KANEKO S, SUGIMACHI K (1990) Immunohistochemical evidence of authocrine growth factors in adenocarcinoma of the human lung. Cancer Res 50: 7077-7080

TOURNIER C, WHITMARSH AJ, CAVANAGH J, BARRETT T, DAVIS RJ (1997) Mitogen-activated protein kinase-kinase 7 is an activator of the c-Jun NH2-terminal kinase. Proc Natl Acad Sci, USA 94: 7337-7342

VIROLLE T, ADAMSON ED, BARON V, BIRLE D, MERCOLA D, MUSTELIN T, DE BELLE I (2001) The Egr-1 transcription factor directly activates PTEN during irradiation-induced signaling. Nat Cell Biol 3: 1124-1128

VISSE E, INOSTROZA J, CABELLO G, PARRA E (2003) The MAP kinases are differently utilized by CD28 and CD2 adhesion pathways in super antigen-activated Jurkat T cells. Biol Res 36: 263-278

VLIESTRA RJ, VAN ALEWIJK DC, HERMANS KG, VAN STEENBRUGGE GJ, TRAPMAN J (1998).
Frequent inactivation of PTEN in prostate cancer cell lines and xenografts. Cancer Research 58: 2720-2723

WIDMANN C, GERWINS P, JOHNSON NL, JARPE MB, JOHNSON GL (1998) MEK kinase 1, a substrate for DEVD-directed caspases, is involved in genotoxininduced apoptosis. Mol Cell Biol 18: 2416-2429

XU X, HEIDENREICH O, KITAJIMA I, MCGUIRE K, NEREMBERG M (1996) Constitutively activated JNK1 is associated with HTLV-1 mediated tumorigenesis. Oncogene 13: 135-142

YEN C, DLIAW K, PODSYPANINA S, BOSE S, WANG I, PUC J, MILIARESIS C, ET AL. (1997) PTEN, putative protein tyrosine phosphatase gene mutated in human brain, breast, and prostate. Science 275: 19431947

YOU L, JAKOWLEW SB (1997) Identification of early growth response gene-1 (Egr-1) as a phorbol myristate acetate-induced gene in lung cancer cells by differential mRNA display. Am J Respir Cell Mol Biol 17: $617-624$

ZAMBLE DB, LIPPARD SJ (1995) Cisplatin and DNA repair in cancer chemotherapy. Trends Biochem Sci 20: 435-439

ZHOU G, MIHINDUKULASURIYA KA, MACCORKLECHOSNEK RA, VAN HOOSER A, HU MC, BRINKLEY BR, TAN TH (2002) Protein phosphatase 4 is involved in tumor necrosis factor-alpha-induced activation of c-Jun N-terminal kinase. J Biol Chem 277: 6391-6398 